\title{
28 de octubre de 1982, una noche para un líder. Radiografía de una imagen para la Historia ${ }^{1}$
}

\author{
Rafael R. TRANCHE \\ Universidad Complutense de Madrid \\ tranche@ucm.es
}

Recibido: 10 de octubre de 2015

Aceptado: 30 de marzo de 2016

\begin{abstract}
Resumen ción. Felipe González.

October 28, 1982, one night for a leader. Analysis of an image for the History
\end{abstract}

El presente artículo aborda la relación entre los medios de comunicación y la Transición española. La prensa tuvo un gran protagonismo durante esa etapa, al hacerse eco e impulsar la acción política en pro de la democracia. Con posterioridad, los medios han intentado gestionar el discurso sobre su significación actual. Dentro de esta lógica, la fotografía ha alcanzado un estatus singular gracias a su papel de cronista y su circulación posterior, una suerte de "memoria gráfica" llamada a contener los momentos decisivos del periodo. En este sentido, la foto de Felipe González y Alfonso Guerra, saludando desde el balcón del Hotel Palace la noche del 28 de octubre de 1982, se ha convertido en un icono de la Transi-

Palabras clave: Transición democrática en España, fotoperiodismo, carisma, elecciones generales 1982,

\begin{abstract}
The present article approaches the relationship between the mass media and the Transition to democracy in Spain. During this stage the press had a leading role, echoing and encouraging political action in favor of democracy. Subsequently, the media have tried to manage the speech on its current significance. Within this logic, photography has reached a unique status thanks to his role as chronicler and subsequent movement, a sort of "graphics memory" called to contain the decisive moments of the period. In this sense, the photo of Felipe Gonzalez and Alfonso Guerra, waving from the balcony of the Hotel Palace on the night of October 28, 1982, has become an icon of the Transition.
\end{abstract}

Keywords: Transition to democracy in Spain, photojournalism, charisma, general elections 1982, Felipe González.

\section{Referencia normalizada}

TRANCHE, Rafael R. (2016): “28 de octubre de 1982, una noche para un líder. Radiografía de una imagen para la Historia”. Estudios sobre el Mensaje Periodístico. Vol. 22, Núm. 1 (enero-junio), págs.: 101123. Madrid, Ediciones Complutense.

Sumario: 1. Transición y medios. 2. Objetivos y metodología. 3. Fotografía y "memoria gráfica". 4. Radiografía de una imagen. 5. A toda página. 6. Reverberaciones de un instante. 7. La ascensión del carisma. 8. Competencias de la imagen. 9. Transfiguraciones de un instante. 10. De la fricción a la ficción. 11. Medios de comunicación, memoria e historia. 12. Referencias bibliográficas.

1 Este artículo es producto del proyecto de investigación $\mathrm{I}+\mathrm{D}+\mathrm{i}$ La construcción mediática del carisma de los líderes políticos en periodos de transformación social: Del tardofranquismo a la Transición (HAR2012-23593), financiado por el Ministerio de Economía y Competitividad de España. 
Cuando sentimos miedo, disparamos. Pero cuando sentimos nostalgia, hacemos fotos. Susan Sontag: Sobre la fotografia.

\section{Transición y medios ${ }^{2}$}

La Transición es una etapa de nuestra historia reciente que ha recibida una atención destacada y constante por parte de los medios de comunicación. De hecho, ha suscitado numerosos tratamientos y aproximaciones cíclicas (monográficos, especiales, series televisivas, conmemoraciones... $)^{3}$, produciendo un curioso fenómeno de apropiación por parte de los mismos; como si la crónica mediática de la Transición y su evocación reciente constituyeran el relato canónico de unos hechos y circunstancias sobre los que los historiadores aún siguen trabajando ${ }^{4}$. Hay razones para ello: muchos medios surgieron durante la Transición y, en cierto modo, protagonizaron el relato de sus acontecimientos. Recordemos las sonadas apariciones de Avui (23/IV/1976), El País (4/V/1976), Interviú (22/V/1976), Diario16 (18/X/1976), Deia (8/VI/1977), El Periódico de Catalunya (26/X/1978) o, antes, Cambiol6 (22/IX/1971), Doblón (20/X/1974) y la última etapa (febrero de 1976 a octubre de 1978) de Cuadernos para el Diálogo, ya como semanario. De ahí que se sientan próximos a su gestión y legado. Además, las luchas por los derechos y libertades generales coincidieron con las reivindicaciones por la libertad de expresión en las que muchas publicaciones se vieron envueltas. Fruto de ello fue la violenta reacción de diferentes sectores (de signo muy opuesto), dando lugar a la censura de contenidos, el secuestro de números de revistas, atentados, procesos y palizas a periodistas... ${ }^{5} \mathrm{Ob}$ -

2 Agradezco a César Lucas, Marisa Flórez, Manuel Pérez Barriopedro y Guillermo Armengol las indicaciones e información que me han proporcionado para elaborar este artículo.

3 A título meramente ilustrativo recuérdese los dos reportajes emitidos en el programa Teleobjetivo de TVE con el título "Operación tránsito" y "Un Rey para todos" (B. Magro y S. Alameda, 1985); la serie documental de TVE La Transición (Elías Andrés, 1995); las series 23-F. El día más difícil del Rey (RTVE, Silvia Quer, 2009); Adolfo Suárez, el presidente (Antena 3, Sergio Cabrera, 2010); Tarancón, el quinto mandamiento (RTVE, Antonio Hernández, 2011); Sofía (Antena 3, Antonio Hernández, 2011). También los sucesivos suplementos especiales y colecciones que los principales periódicos han dedicado al asunto como "Historia de la transición. 10 años que cambiaron España", colección en fascículos de Diario16, 1984; "Historia de la Democracia. La aventura de la libertad. 1975-1995 ", colección de fascículos de El Mundo; "La Transición en imágenes", especial en la web (El País, 7/II/2006); y "El camino de la libertad (1978-2008). La democracia año a año", colección de libros de El Mundo.

4 Un simple ejemplo nos permitirá entender hasta qué punto la historia de la Transición aún debe ser completada con nuevas fuentes y documentos. El sumario del juicio por el 23-F no estará accesible hasta que pasen cincuenta años del golpe o veinticinco de la muerte de los procesados.

5 Los más importantes fueron: Diario 16 sufre un atentado de los GRAPO el 26 de junio de 1977. Ese mismo año, el 20 de septiembre, la Triple A envía un paquete bomba a la redacción de la revista satírica El Papus. En el atentado muere el conserje y hay diecisiete heridos. El director de la Hoja del Lunes bilbaína, José María Portell, es asesinado por ETA el 
sérvese al respecto que hasta el Decreto-Ley de 1 abril de 1977, sobre "libertad de expresión", estuvo vigente la Ley de Prensa de 1966 impulsada por Manuel Fraga. Por su parte, el Ministerio de Información y Turismo, creado como órgano de control de los medios, no desaparece hasta el 4 de julio de 1977 (Decreto 1558/77). A su vez, la emergencia de estas nuevas cabeceras coincidiría con el declive, y posterior desaparición, de la prensa del Movimiento, la cadena de periódicos de titularidad estatal y voz oficial del régimen (Zalbidea, 1996).

Este protagonismo, con frecuencia asumiendo la voz de una nueva opinión pública carente entonces de cauces de expresión, se convirtió en un instrumento propicio para la acción política. "El privilegiado estatus de la prensa española, desde 1966, le permitió desarrollar un papel relevante en el intenso debate público de los primeros años de la Transición a la democracia. Hasta las elecciones de junio de 1977 siguió actuando como "Parlamento de papel", con la diferencia de que, a partir de la muerte de Franco, pudo acoger en sus páginas a actores políticos hasta entonces prohibidos" (Zugasti, 2008: 65). Es más, esta colusión de intereses “...contribuyó decisivamente a amortiguar las tensiones del momento y a crear un espacio de consenso sobre el que asentar las frágiles instituciones de la democracia" (Fuentes Aragonés, 2009: 64). Ahora bien, esta influencia debemos formularla en términos cualitativos, pues como se han encargado de demostrar diversos estudios, la llegada de la democracia no supuso un incremento especial en el número de lectores ni en la tirada de las publicaciones: "El restablecimiento de la democracia no ha supuesto -como algunos aventuraban- una etapa de fuerte expansión de la prensa" (Iglesias, 1985: 436). Incluso, muchas de esas nuevas cabeceras tuvieron una existencia efímera: "Apenas aumentó el número de lectores de prensa entre 1975 y 1982... A los muchos nacimientos de periódicos y revistas correspondió una cifra igualmente alta de cierres tanto de antiguos títulos como de nuevos. La oferta desbordaba a una demanda que se comprobó no era tan intensa como se predecía" (Barrera, 1997: 14).

Por último, y para reforzar esta autoconciencia de los medios, los principales historiadores que han estudiado el periodo coinciden en señalar la función determinante que la prensa cumplió en la consolidación de la democracia (Tusell, 1997; Powell, 2001; Preston, 2003).

\section{Objetivos y metodología}

Dentro de este contexto histórico, queremos estudiar específicamente el papel que la fotografía de prensa desempeñó en la captación de esta nueva realidad democrática. A su vez, interrogarnos por el modo en que algunas de las imágenes resultantes han acabado configurando una especie de canon visual de la Transición, sancionado cíclicamente por los propios medios. Por tanto, se trata de confrontar dos lecturas: la del

28 de junio de 1978. La extrema derecha envía un paquete bomba a la redacción de $E l$ País, el 30 de octubre de 1978, que ocasiona un muerto y dos heridos. José Javier Uranga, director del Diario de Navarra, sufrirá un atentado, también de ETA, el 22 de agosto de 1980. Antes, José Antonio Martín Soler fue secuestrado y torturado por la extrema derecha tras publicar en Doblón (14/II/1976) un reportaje sobre la Guardia Civil. 
momento de la publicación de una imagen y su reaparición posterior en función de otros intereses. Para ello, procederemos al análisis de varias fotografías emblemáticas, intentando desvelar su capacidad para contener el acontecimiento y generar un consenso duradero en torno a su interpretación. Estas reflexiones previas nos permitirán explorar a fondo un estudio de caso: las imágenes que recogen el saludo de Felipe González y Alfonso Guerra en el balcón del Hotel Palace la noche del 28 de octubre de 1982. Reproducidas hasta la saciedad, tanto en versión fotográfica como televisiva, han acabado por representar, a modo de relato sintético, los acontecimientos acaecidos en aquellos días, que condujeron al primer triunfo socialista en unas elecciones generales.

\section{Fotografía y "memoria gráfica"}

La convulsa situación política y social de los últimos años del franquismo y los primeros años de democracia también propició una nueva edad dorada de las revistas con contenido político-social (Triunfo, Cambio16, Doblón, Interviú, La calle...). En ellas la imagen cumple una función esencial. Ante la realidad pautada y rutinaria impuesta por el control y la censura franquistas, renace un fotoperiodismo, con un gran seguimiento y repercusión, que sabe captar la agitación de las calles y las luchas sociales. De hecho, la fotografía alcanza una preponderancia especial frente a la televisión, todavía anclada en sistemas de producción de noticias en soporte cine y con un fuerte control gubernamental ${ }^{6}$. Como afirmaba Susan Sontag: "Las fotografias pueden ser más memorables que las imágenes móviles, pues son fracciones de tiempo nítidas, que no fluyen. La televisión es un caudal de imágenes indiscriminadas, y cada cual anula a la precedente. Cada fotografía fija es un momento privilegiado convertido en un objeto delgado que se puede guardar y volver a mirar" (Sontag, 2006: 35). Además, es una fotografía predominantemente en blanco y negro, realizada en su mayoría por una nueva generación de reporteros gráficos que en muchos casos trabajan por cuenta propia: Manel Armengol, Chema Conesa, César Lucas, Jordi Socías, Marisa Flórez, Manuel Pérez Barriopedro, Guillermo Armengol, Pablo Juliá, Colita, Germán Gallego, Manuel Hernández de León, Ricardo Martín... "La fotografía de prensa vivió en los albores de la democracia un periodo protagónico. Los nuevos reporteros retomaron el viejo espíritu reivindicativo de los pioneros del oficio, conscientes de su responsabilidad y riesgo por fotografiar la lucha común por las libertades democráticas" (Castellote, 2013: 71). A este respecto, los paralelismos con la generación de reporteros que trabajaron durante la Segunda República y la Guerra Civil son evidentes: "es necesario esperar al instante preciso en el que se desmorona el régimen franquista para ver renacer en España un fotoperiodismo en esplendor, heredero directo de la gran tradición fotográfica de los reporteros españoles de los años treinta" (Rodríguez Merchán, 2000: 98). Hay en ambos casos una conciencia histórica del momento que se vive y de la capacidad de la fotografía para dar testimonio de él.

6 Recordemos que será precisamente en 1982, con la inauguración de Torrespaña, cuando se produce la renovación tecnológica que permite introducir equipos ligeros de producción electrónica de noticias (BARROSO y R. TRANCHE: 1996, 136). 
Ese protagonismo ha sido refrendado por los propios medios a posteriori con especiales y monográficos conmemorativos, y fijado por diversas exposiciones antológicas $^{7}$ y catálogos ${ }^{8}$. De este modo, la fotografía parece haber alcanzado un estatus privilegiado como soporte idóneo para fijar el acontecer de la Transición en su tiempo y más tarde conformar una suerte de "memoria gráfica" (sobre acontecimientos y sucesos, pero también sobre personajes). Conviene reparar en esta expresión, memoria gráfica, acuñada por los propios medios, pues otorga a la fotografía un poder de doble signo: la precisión objetiva de lo captado por el ojo de la cámara y la capacidad emotiva de convertirla en fuente de evocación. A diferencia del álbum familiar, la foto de un acontecimiento histórico suscita un reconocimiento colectivo que, bajo determinadas circunstancias, puede cristalizar en un fenómeno de identificación generacional, social o nacional. Dicho de otro modo: genera un consenso en torno a su significación y uso. Pero este consenso no tiene que producirse de modo automático ni instantáneo. Tras su publicación, la foto precisa de una circulación que confronte su capacidad de representación con otras imágenes equivalentes 9 . Esa circulación conlleva dos efectos relacionados: filtra el número de versiones sobre un mismo hecho y condensa su significado. Es decir, al atenuarse con el paso del tiempo su valor informativo, trasciende su significado inmediato y emerge su capacidad de "encarnar" lo acaecido. El resultado es una imagen que acaba prevaleciendo sobre las demás porque nos permite anudar intensamente el acontecimiento con su evocación. Nancy Berthier, en su artículo de este número, la denomina "imagen recalcitrante" aludiendo tanto a su perdurabilidad como a su carácter enigmático. Esta cualidad obedece a ese plus que introduce la mirada del fotógrafo: no solo está retratado el acontecimiento, sino un modo de leerlo y confrontarlo a la erosión del tiempo.

Así, determinados hechos han encontrado su "imagen clave" en la fotografía en detrimento de otros medios. Y, efectivamente, en todo este lapso un selecto grupo de imágenes se han ido decantando hasta representar, según criterio de los medios, la "esencia" de la Transición. Lo singular de este proceso es que no ha operado únicamente sobre los grandes acontecimientos, sobre los momentos trascendentales, sino que se han colado otras peripecias, anécdotas o situaciones insólitas que la imagen

7 Las exposiciones más destacadas hasta la fecha han sido: España 20 años de democracia, Agencia EFE, 1997; 25 años después. Memoria gráfica de una Transición, Comisarios: Miguel Gómez, Luis Magán y Eduardo Rodríguez Merchán, Madrid, Fundación Telefónica, 2000; Tiempo de Transición (1975-1982), Fundación Pablo Iglesias, Madrid, 21 junio-15 septiembre 2007; De la Transición Democrática al siglo XXI. 30 años de fotografía EFE, Agencia EFE, Albacete, 2008.

8 Los catálogos más importantes han sido: España 20 años de democracia, Madrid, Agencia EFE, 1997, 25 años después. Memoria gráfica de una Transición, Obdulio Martín Bernal, Eduardo Rodríguez Merchán, Fundación Telefónica, 2001; La Transición. Memoria gráfica de la historia y la sociedad españolas del siglo XX, Madrid, El País, 2006; Tiempo de Transición (1975-1982), Fundación Pablo Iglesias, Madrid 21 junio-15 septiembre 2007.

9 Esta dinámica se ha multiplicado exponencialmente con la aparición de las ediciones digitales de periódicos y las miles de páginas web que pueden expandir una imagen partiendo de un contexto ya definido por el medio. 
fotográfica ha elevado a la categoría de símbolos de una época ${ }^{10}$. Es el caso de la fotografía de Félix Lorrio, que capta a una pareja desnuda y subida a la estatua de Daoíz y Velarde durante las fiestas de Malasaña de 1976; la de César Lucas, que registra una manifestación el 22 de junio de 1976 con un niño en primer término puño en alto; o la foto de Marisa Flórez de la entrega de Premios Populares Pueblo en febrero de 1978 cuando Susana Estrada deja ver uno de sus pechos ante la mirada perpleja del, entonces alcalde, Tierno Galván. Fotografías que, más allá de reflejar una situación concreta, han tenido una amplia difusión posterior como emblemas de un cambio de mentalidades y de un país en transformación. Imágenes, por tanto, que han conseguido trasmutar su carácter anecdótico para representar la recuperación popular de la calle, las movilizaciones sociales o el llamado "destape".

Cuestión compleja sería delimitar por qué estas imágenes y no otras con atributos semejantes, evaluar su representatividad y hasta qué punto fueron realmente adoptadas por la sociedad de su tiempo o son la forma actual del consumo mediático de imágenes pretéritas.

Si los casos anteriores pueden suscitar cierta controversia respecto a su función simbólica, no ocurre así con las fotos de acontecimientos o momentos históricos. Por ejemplo, la foto de Adolfo Suárez sentado solo en la bancada azul del Congreso, tomada por Marisa Flórez el 25 de septiembre de 1979 y publicada al día siguiente en la portada de El País, es el resultado de dos operaciones: su captación y la maquetación posterior en la que se enfatiza el primer hallazgo. Al reencuadrarse de manera tan ostensible, queda aparentemente descompensada, mal compuesta, y no tenemos más remedio que preguntarnos por lo que falta en ese espacio sobrante: todo un lado de la bancada azul. Al tiempo, es inevitable pensar que ese espacio vacío se prolonga tanto por la izquierda como se clausura abruptamente por la derecha. La mirada, casi ausente, y el reducido espacio que ocupa en el conjunto, potencian esa idea de soledad en su acción política, de líder caído. Pero si la ubicamos en su contexto político la imagen incorpora otros matices: estamos en el Parlamento y esa situación implica dejar aislado el poder ejecutivo frente al legislativo. El pie de foto lo patentiza: "Al iniciarse ayer la sesión parlamentaria, el presidente Suárez estuvo solo en el banco azul". El paso del tiempo otorga a esta imagen un carácter existencial (intensificado tras la reciente muerte de su protagonista) en el que un espacio, siempre poblado y activo, parece habitado por un solo ser. Fuera de las coordenadas precisas en que fue captada, sin pie de foto, denota una circunstancia general: la pérdida de poder de Suárez frente a las luchas internas y la descomposición de su partido. Y así es como recurrentemente se ha leído. Por ejemplo, en Anatomía de un instante, la obra de Javier

10 Recientemente, se hacían eco de estas tesis en uno de los artículos de la publicación colectiva La transición española. Nuevos enfoques para un viejo debate. Siendo novedoso el proponer la fotografía como fuente documental para establecer la historia de la Transición, lo llamativo es que el autor asumiera la representatividad de las imágenes establecidas por los propios medios. Véase al respecto, DÍAZ BARRADO, Mario P., "Las fotos de la Transición” en CHAPUT, Marie-Claude; PÉREZ SERRANO, Julio (Eds.), (2015): La transición española. Nuevos enfoques para un viejo debate, Madrid, Biblioteca Nueva. 
Cercas que novela el 23-F, donde es interpretada como "un emblema de su soledad casi absoluta" (Cercas, 2009: 133).

Recientemente, la serie documental Ochéntame otra vez, nacida al socaire de Cuéntame cómo pasó, dedicaba en su segunda temporada un episodio a las fotografías emblemáticas de la década de los ochenta en España: "La década en un clic" (emitido el 23 de abril de 2015) ${ }^{11}$. Más allá de su tono divulgativo, lo revelador es que el discurso asumido por el programa daba por sentado el carácter sustitutorio de esas imágenes por los acontecimientos que representan. Es más, venía a reiterar, con la anuencia cómplice de sus autores, las fotografías que componen ese "canon visual" de la Transición. Al tiempo, un efecto colateral ratificaba esta idea: en aquellos casos donde existían imágenes de diversos medios sobre un mismo acontecimiento, la imagen televisiva resultaba menos elocuente, pese al plus sonoro y de movimiento, frente a la capacidad sintética de la fotografía (derivada, como decía Sontag, de su intensa relación con el momento preciso de la captación).

En suma, habría que anotar el afán de los programas, publicaciones y exposiciones posteriores por fijar las imágenes canónicas de la Transición, aquellas que serían paradigmáticas, incontrovertibles y, en último extremo, reconocibles hasta alcanzar un consenso popular.

\section{Radiografía de una imagen}

Sobre este controvertido corpus queremos detenernos en una fotografía que contiene todos los ingredientes necesarios para formar parte de él. El modo en que se obtiene y es publicada, el proceso por el cual se convierte, entre otras similares, en el emblema de un momento, nos permitirá constatar esta singular preeminencia que la fotografía alcanza como relator de la Transición. Además, es una imagen que goza en la actualidad de una extraordinaria popularidad, pues parece abrochar varios acontecimientos a la vez: las elecciones generales de 1982, el triunfo del partido socialista, el primer gobierno de izquierdas en democracia y el definitivo encumbramiento político de Felipe González como líder carismático. Se trata de la foto, ya aludida, de Felipe González y Alfonso Guerra saludando desde la ventana de la suite 110 del hotel Palace en Madrid, la noche del 28 de octubre de 1982, tras conocer el resultado triunfal de las votaciones. La lectura que hoy nos parece prístina no tuvo la misma significación en su tiempo y ha precisado de una serie de mediaciones y procesos en los que ha sido determinante el papel desempeñado por los medios.

Recorramos el camino que nos lleva a su aparición y más tarde a su transformación y encumbramiento.

La noche del 28 de octubre, tras el cierre de los colegios electorales, el partido socialista instala su cuartel general en el Hotel Palace, a escasos metros del Congreso de los diputados. En los salones del hotel se celebra una fiesta a la que asiste lo más granado de la progresía del momento. Una pantalla de vídeo gigante, con imágenes de lo que ocurre en el interior y de TVE, anima a los numerosos congregados en la calle.

11 En referencia a sus contenidos se afirma lo siguiente en la página web de TVE: "El espacio pretende ser una revisión divertida e interesante de nuestro pasado más reciente" (sic). 
Felipe González llega hacia las 11 de la noche al hotel acompañado, entre otros, por Julio Feo, el coordinador de la campaña, y Alfonso Guerra. Entran por un acceso lateral para no ser vistos y se alojan en la mencionada suite. A partir de este momento se producirá un llamativo reparto de papeles entre los dos principales líderes socialistas. A las 00:30 h., ante la ausencia de datos oficiales por la "caída" del sistema informático del Ministerio del Interior, Alfonso Guerra ofrece una rueda de prensa dando los resultados de un muestreo, realizado por el propio partido, a pie de urna: el PSOE es el claro vencedor. Este fallo del dispositivo ministerial permite a Guerra arrogarse una función oficiosa de portavoz (que vaticina su rápida asimilación de los entresijos del poder). Por fin, los primeros datos oficiales aparecen hacia la 1 de la madrugada y confirman los del sondeo. Poco más tarde, a las 2:35 h., Felipe González irrumpe en uno de los salones del hotel, escoltado por Alfonso Guerra y Julio Feo. Al llegar al estrado, González pide calma a los asistentes con gesto sereno y pronuncia un breve discurso ante los medios mientras Guerra (que ha sacado de su bolsillo previamente unos papeles y los ha colocado en el atril) permanece muy cerca detrás de él ${ }^{12}$. Es decir, asume todo el protagonismo y adopta una actitud "institucional", como si fuera presidente in péctore ${ }^{13}$. El tono del mismo así lo hace entender: "Desde este mismo instante, quiero hacer un llamamiento a las fuerzas políticas, a las instituciones, a las comunidades autónomas, a las diputaciones, a los ayuntamientos, a los sindicatos, a las organizaciones empresariales, a los medios de comunicación y, en fin, a todos los sectores de la vida nacional, para que se sientan integrados y presten su apoyo participativo en la tarea común de consolidar definitivamente la democracia en España". Por tanto, la comparecencia se convierte en un primer discurso presidencial en vez de partidista. El momento es captado en directo por TVE. Una nube de fotógrafos fija también la escena. Se diría que esta es la imagen llamada a perdurar como representación de la victoria socialista. Por ejemplo, la foto realizada por Chema Conesa, publicada por El País al día siguiente, que recoge un momento de su alocución ante la atenta mirada de Guerra y Tierno Galván.

Sin embargo, cuando ya parece todo dicho y resuelto, se produce una inesperada reaparición. A las 3:15 h. Felipe González, acompañado de Alfonso Guerra, se asoma al balcón de la suite y saluda a los miles de congregados que aún permanecen en la calle. Varios reporteros apostados entre la gente captan la escena. En palabras de Julia Navarro, quien escribió la crónica para el diario Pueblo (29/X/1982): "Felipe González salió a uno de los balcones del hotel y, agarrado de la mano de Alfonso Guerra, con los brazos juntos y apretados en alto, saludó y agradeció la asistencia de todos los que allí estaban celebrando la victoria socialista”. Para $A B C$ (M. Bernal, 29/X/1982), el momento no revistió una especial trascendencia: "Los pequeños grupos salían a buscar sus coches, cuando alguien vio más o menos visiones y dijo que Felipe estaba en la ventana saludando, con lo que la buena gente se puso a aplaudir otra vez con ganas".

12 Las imágenes grabadas por TVE no permiten apreciar con precisión este detalle, pues varias personas se interponen delante de la cámara que los sigue hasta el estrado.

13 Actitud que contrasta con la discreta intervención de los miembros del gobierno saliente a lo largo de la noche electoral. 


\section{A toda página}

Poco después, salen las primeras ediciones de los periódicos. Todos llevan a sus portadas el resultado de las elecciones. La mayoría de ellos destacan el arrollador triunfo socialista y buena parte proclaman ya presidente al candidato socialista. Sin embargo, hay algo mucho más importante respecto a su protagonismo: con distintas modulaciones, todos incluyen su foto en la portada. Y, dicho sea de paso, la mayoría de las principales cabeceras no utilizan fotos del día (salvo El País, Informaciones, Diario16 y La Voz de Galicia). Incluso, algunos medios destacan un factor clave: su triunfo personal. "Gobernará Felipe", se lee en la foto a toda página de la portada de Pueblo; "Felipe barre", titula El Periódico; y "Felipe gana", destaca La Vanguardia. La utilización del nombre de pila añade un punto de familiaridad, de cercanía que nos advierte de la singularidad del carisma que el dirigente socialista ha acumulado en los primeros años de la democracia y la personificación del partido en torno a su figura. A ello habría que sumar los reportajes que aparecen poco después en varios periódicos mostrando la cara íntima y familiar del futuro presidente ${ }^{14}$.

Pero reparemos en un primer detalle llamativo: la foto del balcón no está en ninguna de estas portadas. Hay una primera explicación a esta ausencia: el saludo se produce a una hora en la que los periódicos ya están cerrando sus primeras ediciones. De hecho, la de La Vanguardia sale antes, 3 de la madrugada, de que se produzca la escena. Mas si revisamos en el interior de todas estas ediciones, descubrimos que hay una foto del saludo en la página 7 de Diario16 y otra en la página 4 de Informaciones. Al día siguiente, El País publicaba un amplio reportaje sobre la celebración socialista de la noche electoral que contenía una imagen del saludo y El Alcázar incluía igualmente la foto en la página 9. Por último, la revista Interviú, en su edición del 3 de noviembre, reproducía una foto a gran tamaño, dentro de un especial sobre las elecciones. Es decir, la acción no pasó desapercibida y varios medios se hicieron eco de ella como parte de la crónica de la noche electoral, si bien no se le concedió especial relevancia a la imagen resultante. Ahora bien, estos medios reprodujeron distintas fotos del saludo. Hay, al menos, cinco versiones publicadas del momento:

1. La foto distribuida por EFE, tomada por Manuel Pérez Barriopedro desde un punto de vista lateral a la derecha del balcón, que incluyen Diario 16, El Alcázar e Informaciones, este último con un reencuadre que aísla a los dos prota$\operatorname{gonistas}^{15}$ (fig. 1).

\footnotetext{
14 "Felipe González de la Aa la Z" en Ya (30/X/1982), "Felipe González, así es el presidente" en Pueblo (29/X/1982), "Una familia para La Moncloa" en La Vanguardia (30/X/1982), "Los González-Romero cambian de vida" en El diario Vasco (30/X/1982).

15 Para conseguirla Barriopedro se subió al techo de una unidad móvil de TVE.
} 

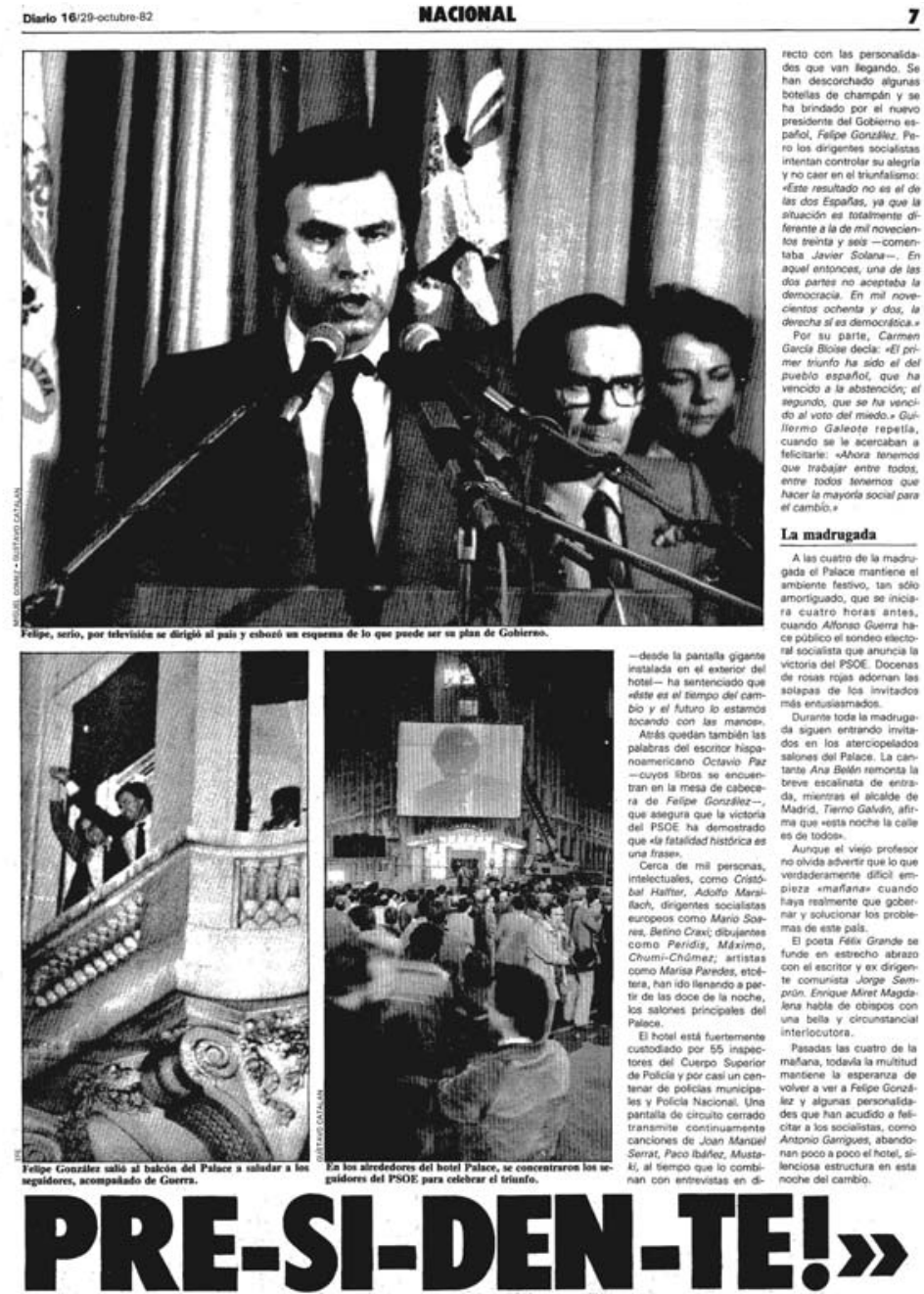

o Bibiotocea Nacional de Espana

Figura 1. Diario16, 29 octubre 1982, p. 7. Foto: Manuel Pérez Barriopedro

2. La foto reproducida por El País, también procedente de EFE, con una variación sustancial: Felipe González saluda solo (con Julio Feo al fondo) desde un punto de vista más frontal, bajo la atenta mirada de Guerra en un balcón lateral (fig. 2). 


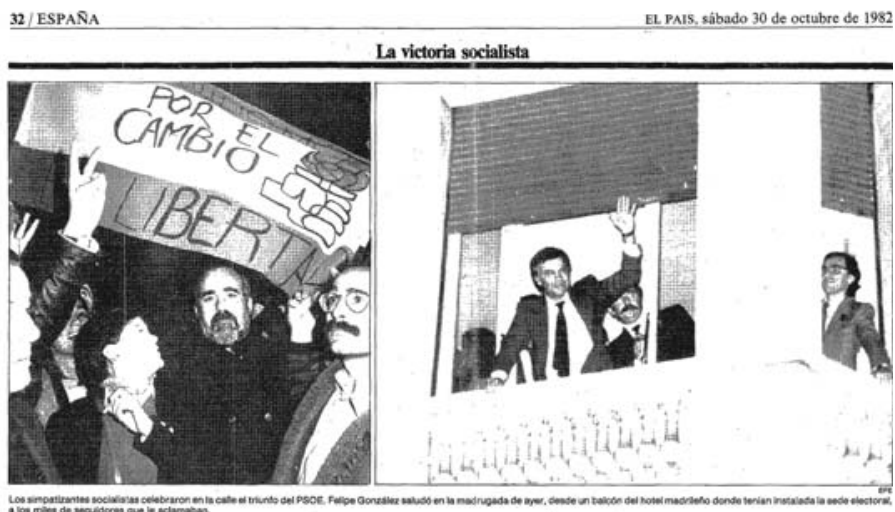

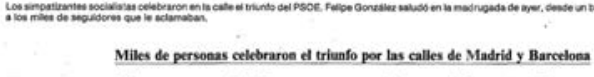

La gran fiesta socialista se prolongó hasta la madrugada

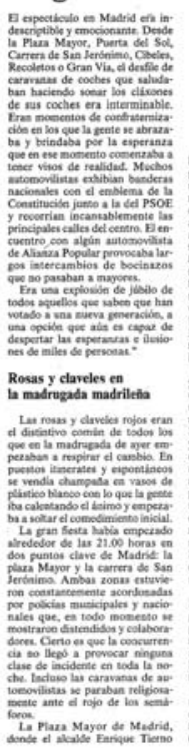

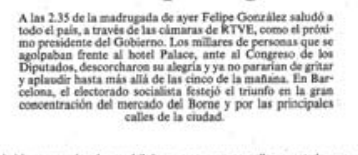

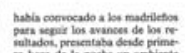
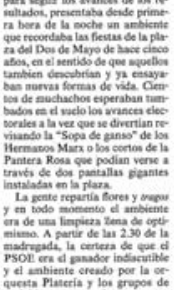

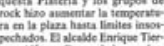

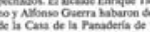
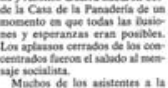

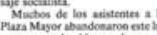
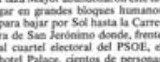

Al cuartiel cectional oel PSOL,

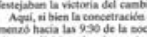

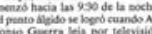
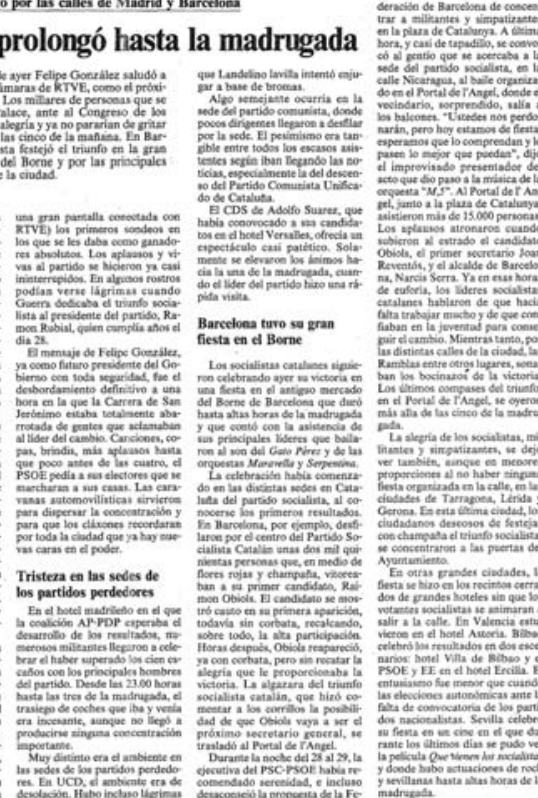

Figura 2. El Pais, 30 octubre 1982, p. 40. Foto: EFE.

3. La foto que distribuye Europa Press, muy similar a la primera de EFE, solo que más próxima y con el brazo de González tapando parcialmente el rostro de Guerra ${ }^{16}$.

4. La foto captada por Paco Junquera, distribuida por la agencia Cover, única compuesta en formato vertical abarcando la ventana del piso superior ${ }^{17}$. Sin embargo, se suele reproducir recortada, incluyendo solo el balcón con los dos protagonistas. A este respecto, su autor afirmaba años después: "No es la mejor

16 Solo hemos encontrado reproducida esta foto en la colección de fascículos Historia de la democracia, editada por El Mundo.

17 Aparece reproducida en las publicaciones, ya mencionadas, Tiempo de Transición (19751982) y 25 años después. Memoria gráfica de una Transición. 
foto, pero si la que se ha publicado más veces... Pregunté si iban a salir al balcón y cuando me dijeron que sí corrí a situarme. Tuve tiempo de realizar tres disparos, en unas condiciones de luz complicadas. Solo valió una de las fotografías" 18 . A diferencia las anteriores, Junquera obtuvo la foto desde una posición casi frontal a la escena, aunque el brazo derecho alzado de Guerra tapa parcialmente su cara.

5. La foto obtenida por César Lucas, que aparece en el no 338 de Interviú. En este caso el formato es apaisado, el balcón ocupa por completo la imagen y la posición, prácticamente frontal, permite que ambos rostros sean claramente visibles. Además, capta como en el caso anterior el instante más elocuente, dejando ver en la otra mano de González un clavel (fig. 3).
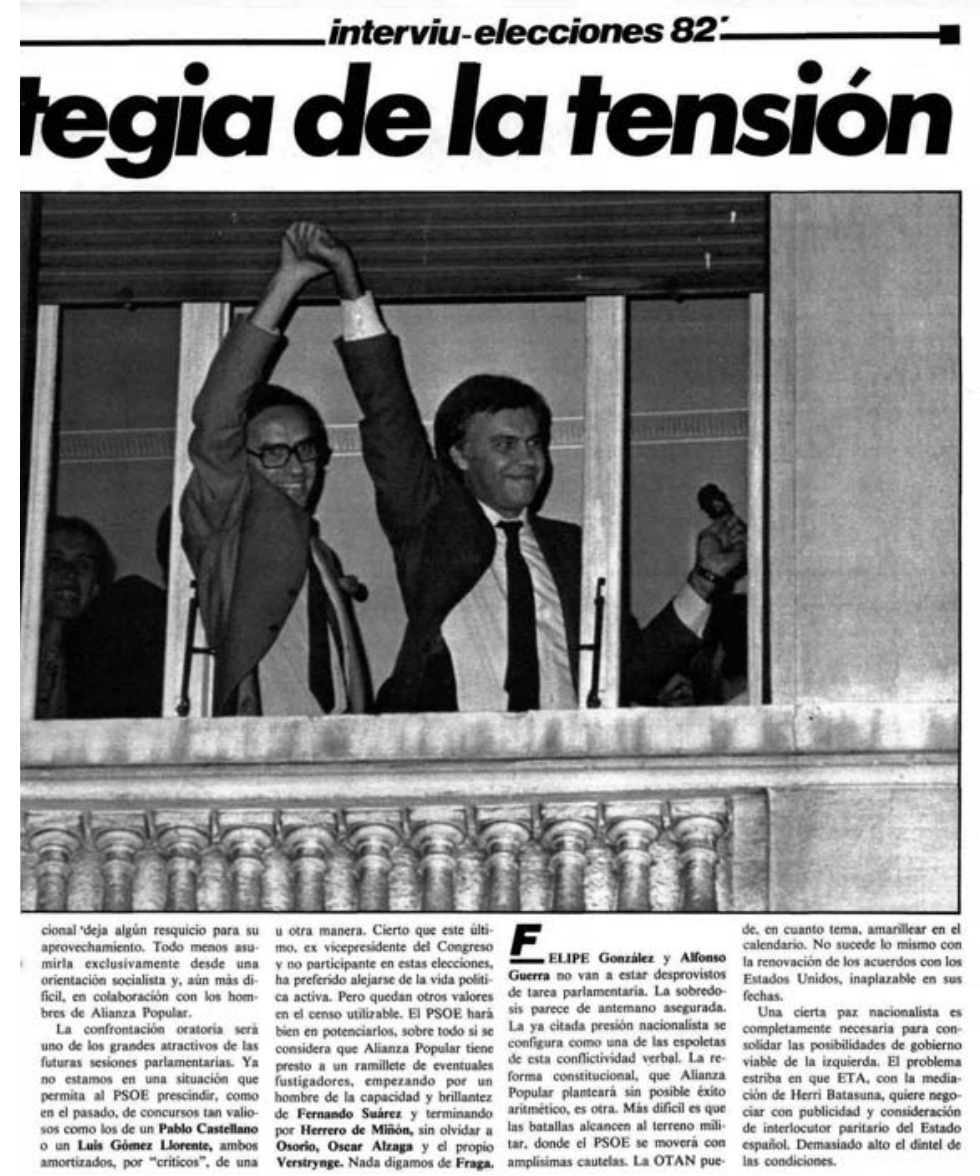

Figura 3. Interviú, 3 noviembre 1982, p. 81. Foto: César Lucas

18 Declaraciones a EFE sobre la exposición “Unos años apasionados”, celebrada en la Galería EFTI 4/III/2011. 
Precisamente, si hacemos una primera comparación de las cinco versiones descubrimos algo llamativo: todas, salvo una, escogieron el momento en el que Felipe y Alfonso Guerra saludan juntos. Esta disparidad de motivos nos apercibe de una circunstancia olvidada: hubo dos momentos diferentes con sentidos bien distintos. No obstante, todas determinan, para dar relevancia a la escena, aislar el gesto del conjunto; es decir, de lo que había alrededor y en primer término. Esta configuración es fundamental, pues pasado el tiempo intensificará su capacidad de interpelación, elemento que creemos está en la clave de su perdurabilidad. Por tanto, no tenemos una imagen única; lo que hace más complejo el proceso de su reconversión como integrante paradigmático de esa "memoria gráfica".

\section{Reverberaciones de un instante}

Hay un hecho decisivo que marcará el destino de esta imagen. Las elecciones generales de 1982 y el triunfo del PSOE han sido considerados por diversos historiadores como las señales definitivas del final de la Transición. Javier Tusell daba tres razones para ello: el grupo político que tuvo un mayor protagonismo en la Transición fue desplazado del poder y poco después desapareció, los resultados de las elecciones constituyeron un plebiscito a favor del sistema (alejando el fantasma del golpe militar tras la fallida intentona del 23-F) y, además, diez millones de españoles cambiaron su voto, lo que vino a constituir "una especie de profunda cesura con respecto al pasado" (Tusell, 1997: 92). Por tanto, esta imagen podría representar además el momento preciso en el que se clausura la Transición. Algo así como su cristalización. Pero, si bien hoy esta fotografía nos resulta transparente con respecto a su carga simbólica (fin de ciclo, nuevo tiempo histórico, clausura de la Transición...), lo cierto es que estos significados se han ido adhiriendo. Son el resultado de una lectura teleológica que ha completado esta escena palmaria. Dicho de otro modo: no es solo una imagen de su presente, sino de nuestro tiempo. No protagonizó la actualidad de forma destacada, sino el relato que los medios han tejido tras su aparición. Por tanto, en su presentación periodística no fue investida del poder alegórico que ahora le atribuimos ni, en consecuencia, de sus atributos carismáticos.

La cuestión es: ¿por qué esta imagen, este momento y no otro? ¿por qué no la mencionada fotografía de González dirigiéndose a los españoles ante los medios esa noche o cuando se dispone a votar con una nube de fotógrafos alrededor? Sin duda, este momento está revestido de un aire triunfal, de un convencimiento colectivo en la victoria socialista. La foto tomada por Paco Elvira retrata con precisión esta idea ${ }^{19}$. El punto de vista elegido detrás de las urnas permite ver al candidato socialista rodeado por completo de periodistas con cámaras, micrófonos y magnetófonos, como si el triunfo ya se hubiera consumado. Sin embargo, esta imagen, como la del discurso tras los resultados, carece de un ingrediente esencial: su conexión con el pueblo.

Por otro lado, solo unas pocas imágenes del líder socialista trascendieron ese día. Las más llamativas dan cuenta de una actitud serena, intentando apartarse de los me-

19 Una foto muy similar de Juan Becerril será publicada por Diario16 en la edición del 29 de octubre. 
dios hasta el momento definitivo. Así, El País publicaba el 29 de octubre una foto "íntima" de González (realizada por Pablo Juliá), en casa de Julio Feo, tumbado en un sofá junto a la hija de este. Por su parte, La Vanguardia del 30 de octubre contenía una foto de él solo en la suite del Palace siguiendo los acontecimientos por televisión. Estas dos imágenes son singulares, domésticas, se presentan como fuera del alcance de los medios y serían parte esencial de un "álbum presidencial”; sin embargo, están lastradas por representar un instante previo, con una marca temporal precisa de difusa trascendencia, al triunfo electoral. Son tan complementarias de las anteriores como accesorias.

\section{La ascensión del carisma}

Volvamos a la foto del balcón. Tres factores sobrevuelan la exitosa aura de esa imagen:

La calculada operación de liderazgo que González montó al dimitir como secretario general en el congreso del PSOE en mayo de 1979. Su renuncia estaba motivada por la aprobación de una ponencia en la que se mantenía el carácter marxista del partido. Tras la dimisión, se nombró una comisión gestora que convocó un congreso extraordinario en septiembre de ese mismo año. González volvió para presentarse al cargo y logró un triunfo arrollador. Con ello, pudo controlar definitivamente todos los resortes del partido y, sobre todo, desarrollar la estrategia política del mismo basada en su liderazgo.

- El segundo factor está estrechamente ligado al anterior. Se trata de la estudiada transformación que experimenta el partido bajo la ejecutiva de González de una organización de "masas de base clasista" a un partido de "integración de todo el mundo" (catch-all-party). El término, introducido en los años 60 por Otto Kirchheimer, venía a definir los procesos de desideologización que acometen algunos partidos europeos tras la Segunda Guerra Mundial con el fin de conquistar a un electorado más amplio: "Renuncia a los intentos de incorporar moral y espiritualmente a las masas y dirige su atención ante todo hacia el electorado; sacrifica, por tanto, una penetración ideológica más profunda a una irradiación más amplia y a un éxito electoral más rápido... hoy se considera que los fines de antaño disminuyen el éxito, porque asustan a una parte de la clientela electoral, que es potencialmente toda la población" (Kirchheimer, 1980:331).

- El tercero factor es el diseño de la campaña electoral, en la que el PSOE refina las técnicas del marketing político que había ensayado en elecciones anteriores de 1977 y 1979. La experiencia previa de Julio Feo será decisiva a este respecto. El equipo coordinador monta una campaña a la americana, con un autocar electoral que recorre la geografía española, donde la figura de González fue explotada intensamente con veinte actos en veintiún días. Con ello se pretende dar una imagen de proximidad y cordialidad, extender su encanto a todo el electorado y no solo a sus votantes (Feo, 2008). Como afirma Manuel Antonio Rico en la colección de fascículos "Historia de la democracia": "Tocado con la gracia de una sencilla capacidad para hacerse creíble, aureolado con un atractivo personal que la hagiografía definió enseguida como carisma, González trans- 
mitía una sensación de honestidad y limpieza como la que la sociedad española reclamaba". Al tiempo, tras las derrotas de las elecciones de 1977 y 1979, su imagen en la propaganda se perfiló con un aire de estadista, de hombre de Estado. El cartel principal reproducía el rostro de Felipe, recortado sobre el cielo, con traje y corbata, gesto de visionario y la mirada dirigida al porvenir. Era una foto idealizada, donde el líder socialista ya había "ascendido" a un cielo nimbado, entorno incontaminado idóneo para las promesas electorales. Todo ello, sumado a un eslogan de enunciado simple, "Por el cambio", pero que condensaba el desiderátum de la sociedad española, otorgaban al cartel una apariencia de sueño colectivo próximo a cumplirse.

Llegada la jornada electoral, pues, todo indicaba que el éxito socialista quedaría personificado en la figura de González. De manera que el saludo en el balcón del Palace parece contener el clima emocional reinante ese día. Reparemos en algunas circunstancias de su registro: es una imagen "en caliente", hecha en plena noche electoral, cuando acaban de saberse los resultados y la celebración, que había empezado horas atrás, se transforma en entusiasmo, euforia por una victoria aplastante ${ }^{20}$. Los fotógrafos que consiguieron captar esta escena han destacado su carácter fortuito y la dificultad para obtenerla. Muchos compañeros ya se habían ido, otros permanecían en el interior del hotel y no hubo un aviso formal de que González y Guerra fueran a salir al balcón a saludar. La imagen resultante fue producto del azar, no estaba concebida para la cámara, aunque sus ingredientes previos podían formar parte de una puesta en escena propicia para un líder político. En este sentido, lleva adherida una "dimensión aclamatoria" en la tradición de las imágenes que reproducen el esquema líder-masa con algunos de sus ingredientes característicos: el desnivel entre un espacio elevado (balcón) y la calle, el marco arquitectónico reencuadrando las figuras y su ubicación en un umbral que delimita el espacio interior (suite) del exterior ${ }^{21}$. Además, la disposición en contrapicado de todas las fotos, permite asimilarlo al punto de vista (y la distancia) de los congregados. Salir al balcón, dejarse ver en un ámbito propicio para la aclamación, es un gesto que conecta imaginariamente con toda la población, frente a la comparecencia ante los medios o en la sede del partido. Un baño de masas al viejo estilo, por contraste con el misterio que rodea su actitud desde que llega al Palace: aislado del entorno en una habitación, protegido por su equipo de asesores y sin querer hablar con la prensa. Precisamente, la foto tomada en la habitación del hotel representaría esta actitud: la soledad del que no se atreve a mostrarse y sopesa la responsabilidad que le espera.

Por otro lado, el lugar elegido como cuartel general del partido no pudo ser más propicio y premonitorio. Más allá de sus connotaciones elitistas, un hotel de lujo, hay

20 Recordemos que en esas elecciones el PSOE consiguió la mayoría absoluta más importante de la democracia española: 202 escaños de 350 y 10.127 .392 de votos (un 48,11\%).

21 La imagen de un líder asomado al balcón forma parte de las escenas cultuales prototípicas, donde se naturaliza el efecto de elevación del mismo frente al pueblo; que, al ser invitado a mirar hacia arriba, queda en una posición orante, devocional. 
que pensar en su ubicación: casi enfrente del Parlamento, como si esa proximidad revelara una conciencia previa del triunfo y del gesto simbólico que debía configurarlo. Es más, desde sus habitaciones hay una vista privilegiada del mismo, especialmente en la suite reservada para la ocasión, lo que permite especular con el punto de vista de los protagonistas: en primer término, el pueblo vitoreando a los triunfadores $\mathrm{y}$, al fondo, el lugar desde el que serían investidos y legislarían. A este respecto, hay que evaluar también el protagonismo conjunto que la foto formula. La presencia de Alfonso Guerra denota un poder compartido, anuncia un duunvirato que después se materializaría en la acción de gobierno (aunque más tarde se truncaría). Sin embargo, lo que ha prevalecido es el protagonismo de Felipe. Por más que la foto muestre un equilibrio de presencias y sus manos se unan en agradecimiento y reconocimiento mutuos, es inevitable conferirle a él todo el poder de atracción. Contemplada desde el presente, la figura de Guerra queda igualmente relegada a la de acompañante, en la medida en que Felipe supo arrogarse, con sus luces y sombras, la ilusión colectiva suscitada con las elecciones de 1982.

En este punto, resulta pertinente retomar la comparación entre las cinco versiones, porque si la presencia de Guerra tuviera ese valor subsidiario podría pensarse que la foto más certera, la destinada a perdurar, es la que le relega a un segundo término mirando desde otra ventana $\left(\operatorname{la~}^{\circ} 2\right)$. Esta disposición representaría mejor el reparto de papeles dentro del partido: uno, asumiendo la imagen pública, otro, el muñidor en la sombra; tal y como ocurre en la foto de la comparecencia de González, en la que Guerra también le observa con gesto vigilante. Por su parte, las fotos tomadas desde un lateral, 1 y 3 , no consiguen definir con intensidad el saludo y, en consecuencia, se pierde su poder alegórico ${ }^{22}$. Su lectura es meramente informativa y coyuntural. Por irrelevante que pueda parecer, esta diferencia en la posición de la cámara con respecto al motivo puede ser determinante. Recordemos al respecto la famosa foto de Alfred Eisenstaedt, $V-J$ Day in Times Square. La imagen recoge el momento en que un marino besa a una enfermera, para celebrar la victoria sobre Japón, el 14 de agosto de 1945 en Nueva York. Casualmente, un fotógrafo de la marina estadounidense, Victor Jorgensen, captó la misma escena, solo que ligeramente ladeado y más cerca. Siendo una foto bien concebida, el resultado es completamente distinto, se pierde la original disposición de los cuerpos de la primera, y acaba marcando la diferencia entre un icono del final de la Segunda Guerra Mundial y una imagen que se queda en mera curiosidad ${ }^{23}$.

Las fotos de Paco Junquera $\left(n^{\circ} 4\right)$ y César Lucas $\left(n^{\circ} 5\right)$ se fundamentan en la "copresencia" de ambos políticos juntos, aunque lo más importante es que están mejor enmarcadas y el eje de miradas y el de la cámara son prácticamente coincidentes. Sin embargo, la foto de los dos separados (seguramente representa el momento inicial de la acción) carece de la rotundidad de las anteriores. El gesto de González en solitario, un simple saludo, se atenúa con los otros dos personajes presentes. En la foto de los

22 De hecho, la foto $\mathrm{n}^{\mathrm{o}} 1$ comparte protagonismo con otras en la misma página en Diario16 y El Alcázar.

23 Véase la foto de Jorgensen en: https://en.wikipedia.org/wiki/Victor_Jorgensen\#/media /File:Kissing_the_War_Goodbye.jpg. 
dos juntos el saludo es, al tiempo, un signo de la victoria; pero mientras en la foto de Junquera parece que es Guerra el que levanta la mano de González, en la de Lucas hay una sensación de gesto común. En suma, lo que hoy contemplamos en esa foto es la escenificación de un triunfo compartido sobre el que se despega la consagración definitiva de un líder.

Ahora bien, a todas las versiones les falta el factor interpelativo que la sustenta: la masa. Bien como elemento incorporado en primer término o bien como hipotético contracampo en respuesta a la mirada de sus protagonistas. Como señalábamos antes, esa ausencia la hace especialmente proclive a que el espectador, al contemplarla, se inscriba en ella. Veremos a continuación hasta qué punto esta dimensión ha quedado instalada en la conciencia colectiva.

\section{Competencias de la imagen}

Este testimonio gráfico ha eclipsado otra imagen que, en buena lid, debería compartir las mieles de la posteridad. Se trata de la grabación videográfica realizada por TVE dentro de la exhaustiva y amplísima cobertura de la jornada electoral. Porque, por primera vez en España, se utilizaron las posibilidades de los equipos ENG (cámaras electrónicas con autonomía de grabación) combinados con unidades móviles para establecer conexiones en directo desde los principales focos informativos. Una multiplicación espectacular, novedosa entonces, del efecto de simultaneidad propio del directo televisivo. Todo ello formó parte de un programa especial, "La noche de todos", concebido para seguir los resultados desde el cierre de los colegios hasta la madrugada. Como parte de este despliegue, una cámara de televisión consiguió captar el saludo. Las imágenes contienen el gesto animado durante los breves segundos que abarca. En ellas hay un detalle revelador que ha pasado desapercibido: Guerra y González salen a saludar separados moviendo sus manos derechas. Tras unos instantes, González tiende su mano elevada y parece decirle a Guerra "dame la mano". Entonces, ambas manos se juntan y continúan el saludo. El gesto indica una clara intención de compartir el éxito.

Pero, pese a incluir toda la acción, estas imágenes son deficitarias por el grano videográfico de la época y los flashes que las salpican intentando congelar un instante concreto. La oscilación de la cámara (que recurre al tele para ofrecernos un plano cercano de ambos), la escasa iluminación, la pobreza del color e, incluso, el sonido la alejan de todo rasgo aurático. Porque una de las revelaciones de esta escena es que carece de un sonido definitorio (grito, declaración, mensaje) que podamos atribuir a sus protagonistas. Es una imagen "muda" cuyo único aditamento sonoro es el ambiente exterior. En suma, su poder enunciativo se desactiva a medida que se prolonga su duración.

A diferencia, la imagen fotográfica en su formulación más precisa, la realizada por César Lucas, posee todos los ingredientes necesarios: aísla el gesto espontáneo en el instante preciso, lo convierte en rotundo y decidido, y con el marco espacial idóneo. Es más, el destello, producto del flash empleado, abrillanta la clave nocturna y otorga una apariencia intemporal a la imagen. La habilidad del fotógrafo consiste precisamente en haber conseguido un equilibrio perfecto entre los elementos controlables (composición) y el azar. No es casual, por tanto, que Interviú la reprodujera a gran ta- 
maño, ocupando como único motivo la mayor parte de la página. Con ello subrayaba su valor como documento gráfico autónomo ${ }^{24}$.

Considerando todos estos componentes, esta fotografía revela a fortiori una "ascensión del carisma" de Felipe González; un encumbramiento producto de la asociación de su triunfo con los anhelos de una ciudadanía que, no lo olvidemos, lo aclama por primera vez como presidente electo. Ninguna imagen previa de ese día produce esa conexión líder-pueblo. De ahí que tenga esa dimensión cristalizadora. Es en ese instante, si seguimos la tesis del fin de la Transición con la victoria socialista, donde se puede cifrar dicho triunfo, su llegada a la presidencia y el final de un ciclo histórico.

\section{Transfiguraciones de un instante}

El paso del tiempo ha reforzado estos valores añadidos de la fotografía del balcón. Aunque se siguen difundiendo distintas versiones del momento, la de César Lucas ocupa un lugar destacado en los recordatorios y conmemoraciones dedicadas a las elecciones de $1982^{25}$. Pero lo más llamativo es el estatus que ha adquirido ese momento.

\section{EL PAİS}

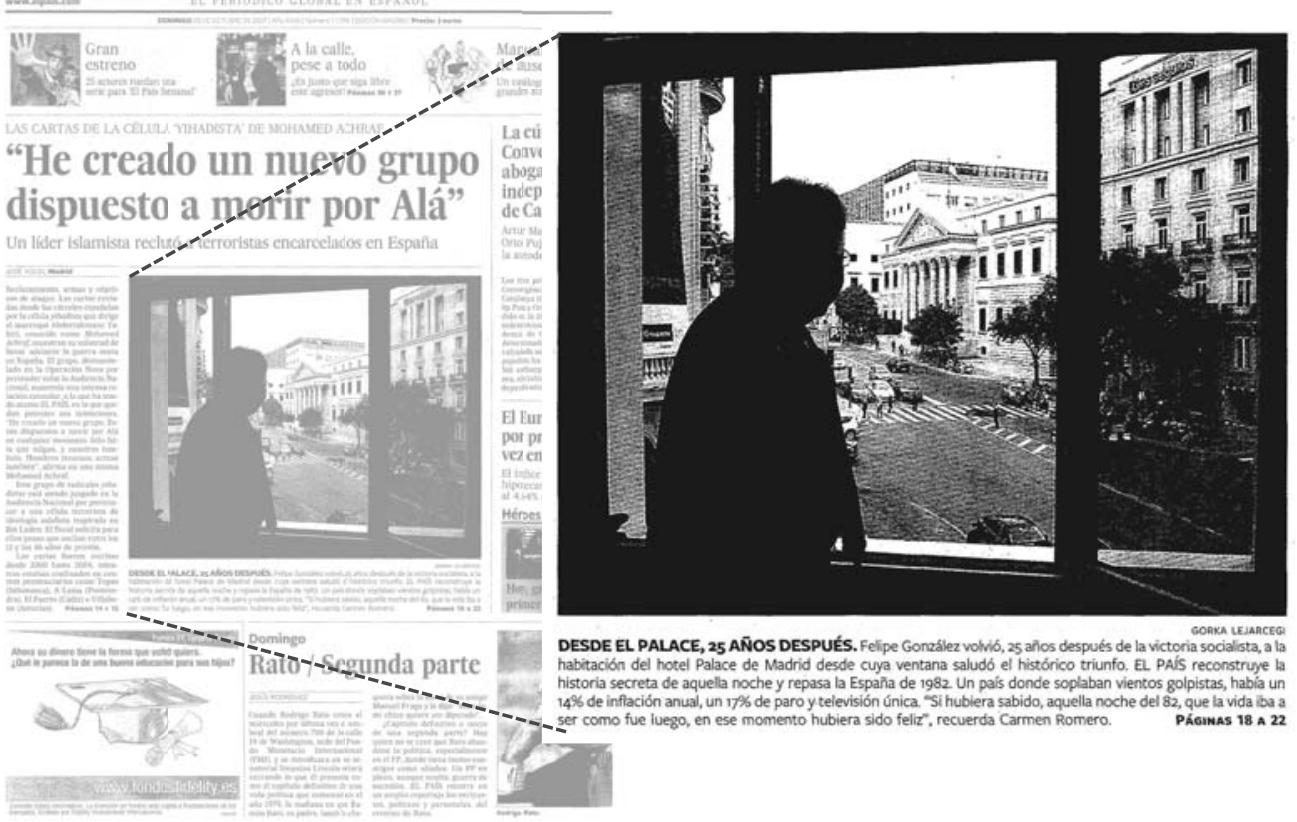

Figura 4. El País, 28 octubre 2007, portada. Foto: Gorka Lejarcegi.

24 La imagen, sin ningún pie explicativo, aparecía dentro del artículo de Lorenzo Contreras "Congreso: la estrategia de la tensión".

25 De nuevo la serie Ochéntame otra vez, en un programa dedicado a la noche electoral de las elecciones de 1982, "La noche del cambio" (emitido el 6 marzo de 2014), otorgaba a la foto de César Lucas la virtud de representar en exclusiva ese momento. 
En su edición del domingo 28 de octubre de 2007 El País llevaba a su portada una foto de Felipe González. Aparecía de espaldas asomado a una ventana sobre un fondo perfectamente reconocible: el Congreso de los diputados. Un pie de foto aclaraba esta escena extemporánea: "Felipe González volvió, 25 años después de la victoria socialista, a la habitación del hotel Palace de Madrid desde cuya ventana saludó el histórico triunfo" (fig. 4). Lo que nos revelaba, por primera vez, esta foto de Gorka Lejarcegi era la visión que había tenido ante sí aquella noche el candidato socialista (por cierto, sin su compañero de triunfo). Ese contracampo, sugerido a través de su mirada de entonces, en el que se podía divisar la Carrera de San Jerónimo y el edifico del Congreso. Sin embargo, la imagen del presente era completamente inane, pues nada había contenido en ella sino la evocación de un instante. Pasados 25 años, el envés de la fotografía, el otro lado del eje de cámara no significaba nada. Ahora bien, ciñéndonos al personaje, su presencia ahí patentizaba la trascendencia de ese momento en el amplio despliegue celebratorio que le dedicaba El País en esa edición. El reportaje coincidía con la exposición conmemorativa del 25 aniversario del triunfo en las elecciones que el PSOE inauguró en su sede en Madrid. La efemérides también fue recordada, con interpretaciones de distinto signo, en las ediciones de ese día de $A B C$ y La Vanguardia. En ambos casos la imagen destacada era, una vez más, el saludo del balcón: “....ambos levantaron las manos entrelazadas, en lo que ha quedado como la foto mítica de aquella victoria electoral", se decía en el artículo de La Vanguardia, ratificando con ello el proceso de "mitologización" que ha experimentado la misma ${ }^{26}$. Es más, el texto se encabezaba con un titular categórico: "El arrollador triunfo del PSOE el 28 de octubre marcó el fin de la transición". De modo que esta sentencia venía a rubricar la lectura teleológica que se ha hecho de la foto como fin de un ciclo histórico.

Poco después, el 1 de diciembre de 2007, El País conseguía una exclusiva sorprendente: juntar a González y Guerra para una entrevista en el Hotel Palace. Más allá del contenido de la entrevista y de concebirla en el lugar de los hechos, lo más llamativo era la inclusión de una nueva foto, realizada por Marisa Flórez, que suponía otra vuelta de tuerca sobre el acontecimiento original: un retrato de ambos asomados a la misma ventana y ocupando los respectivos lugares de entonces. La ausencia de entusiasmo, la sonrisa forzada de los retratados y su transformación física no es lo que convierte esta foto en espectral, sino la inoperancia del gesto tantos años después. Sus miradas, entonces apenas atisbadas pero sostenidas por las miles de personas congregadas ante el hotel, aparecen aquí tan nítidas como insustanciales. Se diría que esta imagen está completamente desmagnetizada, carente del más mínimo carisma; como si el paso del tiempo patentizara ahí la ruptura del hechizo de la sociedad española con sus protagonistas. Como si esta imagen, captada de día, fuese el despertar de un sueño que el tiempo se ha encargado de destruir. En su intento de devolvernos al origen del mito (mismos personajes, mismo lugar, misma posición) esta foto tiene algo de siniestro en su acepción freudiana.

$26 A B C$ optaba por la foto de EFE en la que solo saluda González y La Vanguardia por la foto, también de EFE, en la que saludan ambos. 


\section{De la fricción a la ficción}

Como decíamos antes, esta fotografía ha ido incorporando ingredientes, superponiendo capas de significados en su circulación posterior. Hay una última capa que quizá sea la que la protege de toda contaminación, incluido el declive político de sus protagonistas. Seguramente, habría que calibrarla desde el campo de la historia de las emociones, como parte de un proyecto de ilusión compartida. ¿Qué si no podría explicar la ola de entusiasmo, de confianza en el porvenir que provocó la victoria socialista? En ese sentido, esta imagen ha experimentado un recalentamiento para adscribirla a un fenómeno de emoción colectiva, impulsado por una campaña electoral muy efectiva, donde la idea de cambio fue directamente asimilada como necesidad propia por los votantes. Algo de este "espíritu" pretendía reproducir la serie Cuéntame cómo pasó, en su decimoquinta temporada, con el episodio 261, "La noche de todos"27. El título se refería, claro está, al programa especial realizado por TVE la noche del 28 de octubre de 1982. Como punto de arranque, la narración asumía las tesis establecidas sobre la trascendencia de ese día: "Aquellas elecciones estaban destinadas a marcar a fuego nuestro futuro... Aquella noche de 1982 todos sabíamos que iba a suceder algo importante". Pero lo más relevante era el giro sustancial que introducía la trama: la separación de los protagonistas, Antonio y Mercedes, por la infidelidad del primero. Más allá de este trasunto folletinesco, la serie enhebraba, como es su costumbre, la peripecia familiar con la historia española reciente. En este caso, haciendo coincidir el estallido de la ruptura con la noche electoral. Así, el final del capítulo se formulaba con una estructura de montaje paralelo: Mercedes echa de casa a Antonio. Acto seguido, se muestran sus reacciones por separado: ella en su habitación, él en el descansillo y después en casa de Miguel. Lo singular de este dispositivo es que se desarrolla sin palabras, otorgando la interpretación del desenlace a la canción que suena de fondo: Todo cambia, en versión de Mercedes Sosa. La poderosa voz de la cantante argentina, fagocitando las torpes imágenes del desconsuelo, y las concomitancias de la letra con la situación emocional y política, hacen que el final se abisme hacia la conmoción melodramática. Sin embargo, cuando todo parece contado, irrumpen unas imágenes documentales del triunfo socialista: la celebración en las calles, la fiesta en la Plaza Mayor y... el saludo desde el balcón del Palace. La habilidad de los guionistas consiste, ni más ni menos, que en reservar esta imagen como cierre y completar el contracampo ausente con una escena de los hijos de los protagonistas en la calle mirando, supuestamente, hacia el balcón (fig. 5). El procedimiento establecido es preciso: reconstruir el eje de miradas entre los protagonistas del momento histórico y la sociedad española, representada aquí por los hijos de los protagonistas como encarnación de la generación del cambio. Pese a lo heterogéneo de este eje, un puente imaginario entre la ficción y el acontecimiento, la serie de planos y contraplanos cuadra la idea: la "ascensión carismática" de Felipe González al calor de esa comunión colectiva. De modo que la encrucijada de los protagonistas, abocados a un cambio trascendental en sus vidas, se integra en una encrucijada colectiva: la de un país que esa noche espera un nuevo tiempo histórico. Así lo enfatiza el narrador,

27 Emitido el 6 de marzo de 2014. El genérico de esa temporada incluía una imagen fugaz de la versión televisiva del saludo en el balcón. 
sellando estas últimas imágenes: "La noche del 28 de octubre de 1982 todo el mundo sintió que empezaba una nueva etapa para España. Algunos con recelo, otros con rabia, pero la inmensa mayoría con ilusión y alegría. Y ajenos al drama que estaba ocurriendo en nuestro viejo piso de San Genaro, mis hermanos y yo nos unimos a las miles de personas que salieron a la calle a expresar su alegría sin saber que las cosas iban a cambiar para todos nosotros mucho más aún de lo que imaginábamos". Ahora bien, si lo pensamos detenidamente, solo la coincidencia anuda estas dos formulaciones del cambio, solo un artificioso giro de guion incrusta uno sobre otro para convertirnos, como los personajes, en sujetos momentáneos de la Historia.

En suma, con esta súbita irrupción del registro histórico el desenlace se desliza hacia ese territorio que tantos réditos ha dado a esta serie: la memoria sentimental.

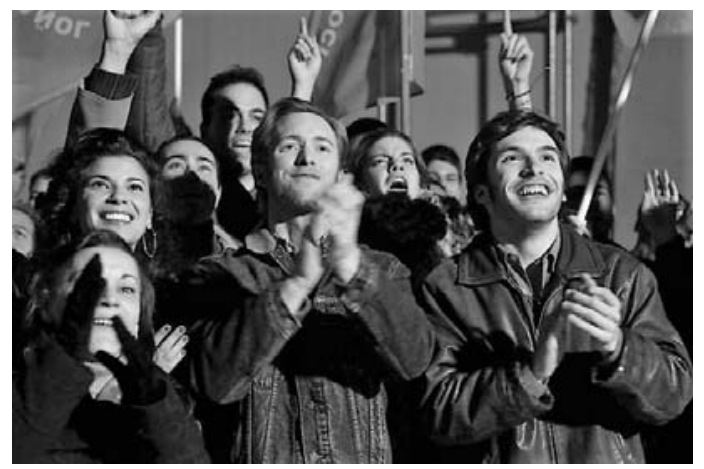

Figura 5. Cuéntame cómo pasó, epis. 261 (TVE, 6 marzo 2014)

\section{Medios de comunicación, memoria e historia}

Los resultados de nuestro estudio de caso suscitan varias reflexiones finales. La primera hace referencia al modo en que los medios de comunicación fueron actores privilegiados de la Transición. No solo a través de su línea editorial y el tratamiento prioritario dado a la acción política (como se han encargado de desvelar estudios precedentes), sino también otorgando un papel destacado al registro visual de dicha actividad. El fotoperiodismo de esos años supo responder ante una situación tan convulsa como imprevisible. Sus imágenes han sido el soporte privilegiado para fijar posteriormente los hitos de este periodo. Además son fruto de un consenso, tejido desde el discurso de los medios, respecto a lo que significó ese momento histórico. De manera que hoy los acontecimientos principales de la Transición y sus imágenes asignadas parecen las dos caras de una misma moneda. Cierto es que las disimetrías y desfases entre unos y otras son evidentes. Como afirmaba Susan Sontag: "Una fotografía -toda fotografía- parece entablar una relación más ingenua, y por lo tanto más precisa, con la realidad visible que otros objetos miméticos. Pero a pesar de la supuesta veracidad que confiere autoridad, interés, fascinación a todas las fotografías, la labor de los fotógrafos no es una excepción genérica a las relaciones a menudo sospechosas entre el arte y la verdad" (Sontag, 2006: 19). Por tanto, esa "memoria gráfica" de la Transición no deja de ser una reconstrucción, un relato interesado que, rescatando unas imágenes, escamotea otras. 
Sin embargo, el poder sintético de la imagen, asociado al texto informativo que la contextualiza, han dado como efecto un cliché productivo. Mas sería un error observar estas imágenes únicamente como el resultado de una operación mediática destinada a obtener réditos de escenas pretéritas. Su reconocimiento popular va más allá de las pretensiones del medio por imponer un canon visual o una galería de imágenes seminales. Es preciso además un acuerdo con el lector, el público, para que se conformen en una experiencia común, ya sea vivida o asumida como parte del imaginario colectivo. Hay una circunstancia añadida: nos encontramos ante unas imágenes donde, una vez abierta la espita de la libertad, late una realidad trepidante. Es inevitable adherir a estas imágenes la huella de un nuevo tiempo histórico en el que todo estaba por hacer. Esta dimensión enriquece, como hemos visto, la lectura presente de muchas imágenes y permite explicar en parte su perdurabilidad. Al tiempo, es un lugar fértil para acomodar la memoria y conceder, con la complicidad de otros, que esas imágenes representan la Transición.

Estos factores justificarían el éxito inextinguible de algunas imágenes soldadas a la Transición. La foto de González y Guerra en el balcón del Palace participa de todos estos sobreentendidos: evoca un acontecimiento trascendental para el destino de la Transición, pero a la vez contiene en sus márgenes una efervescencia colectiva espontanea. Es la imagen que da paso a un nuevo ciclo político, pero de ella dimana un aura que el líder socialista supo rentabilizar durante varias legislaturas (el término "felipismo", pese a su componente peyorativo, sería un signo de ello). Mas, acotada la función histórica que porta, su poder visual no se basa solo en lo captado, sino también en quienes sostienen la escena con la mirada. $Y$ esa mirada, gracias al azar fotográfico, permite al espectador actual integrarse en la imagen, como formulaba abiertamente la serie Cuéntame cómo pasó, participando a la vez del optimismo de entonces y de las (in)certidumbres del presente. Por eso, no deja de ser paradójico que esta imagen "imprevista", abierta, acabara siendo la llamada a prevalecer sobre todas las imágenes previas de aquella jornada.

\section{Referencias bibliográficas}

BARRERA, Carlos (1997): "Poder político, empresa periodística y profesionales de los medios en la transición española a la democracia". Comunicación y Sociedad, 10 (2), pp. 7-46.

BARROSO, Jaime y R. TRANCHE, Rafael (eds., 1996): “Televisión en España 19561996". Archivos de la Filmoteca n ${ }^{\circ} 23-24$, Valencia, Filmoteca de la Generalitat Valenciana.

CASTELLOTE, Alejandro (2013): "España: fragmentos propios y ajenos de nuestro imaginario visual”. España a través de la fotografía, Madrid, Fundación Mafre.

CERCAS, Javier (2009): Anatomía de un instante. Barcelona, Mondadori.

DÍAZ BARRADO, Mario P. (2015): "Las fotos de la Transición", en CHAPUT, Marie-Claude y PÉREZ SERRANO, Julio (Eds., 2015): La transición española. Nuevos enfoques para un viejo debate. Madrid, Biblioteca Nueva. 
FEO, Julio (2008): Déjame que te cuente. Madrid, Espejo de Tinta.

FUENTES ARAGONÉS, Juan Francisco (2009): "De la confrontación al consenso: el papel de la prensa en la Segunda República y la Transición”. En QUIROSACHEYROUZE Y MUÑOZ, Rafael (ed., 2009): Prensa y democracia: los medios de comunicación en la transición. Madrid, Biblioteca Nueva.

GÓMEZ, Miguel; MAGÁN, Luis; y RODRÍGUEZ MERCHÁN, Eduardo (2000): 25 años después. Memoria gráfica de una Transición. Madrid, Fundación Telefónica.

IGLESIAS, Francisco (1989): "Las transformaciones de la prensa diaria". En ÁLVAREZ, Jesús Timoteo (Ed.): Historia de los medios de comunicación en España. Periodismo, imagen y publicidad (1900-1990). Barcelona, Ariel.

KIRCHHEIMER, Otto (1980): "El camino hacia el partido de todo el mundo". En LENK, Kurt y NEUMANN, Franz (coord.): Teoria y sociología críticas de los partidos politicos. Barcelona, Anagrama.

NAVARRO, Julia: “Apoteosis en el Palace”. Pueblo, 29 octubre 1982.

PAZ, Rosa: "Y Felipe se sintió abrumado". La Vanguardia, 28 octubre 2007.

POWELL, Charles (2001): España en democracia, 19752000. Barcelona, Plaza y Janés.

PRESTON, Paul (2003): Juan Carlos. El rey de un pueblo. Barcelona, Plaza y Janés.

RICO, Manuel Antonio (1995): "Felipe barre pero ni brinda ni da las gracias". En Historia de la Democracia. La aventura de la libertad. 1975-1995, Madrid, colección de fascículos de El Mundo, pp. 586-593.

SONTAG, Susan (2006): Sobre la fotografia. México, Anagrama.

TUSELL, Javier (1997): La transición española. Madrid, Historia 16.

ZALBIDEA BENGOA, Begoña (1996): Prensa del movimiento en España: 19361983. Bilbao, Universidad del País Vasco.

ZUGASTI, Ricardo (2008): "El papel de la prensa en la construcción de la democracia española: de la muerte de Franco a la Constitución de 1978". Confines de Relaciones Internacionales y Ciencia Política. Volumen 4, número 7, pp. 5368.

Rafael R. Tranche es Profesor Titular en la Universidad Complutense de Madrid, Departamento de Comunicación Audiovisual y Publicidad I. Es coautor, con Vicente Sánchez-Biosca, de NO-DO El tiempo y la memoria (2000) y El pasado es el destino. Propaganda y cine del bando nacional en la Guerra Civil (2011). Su último libro es Del papel al plano. El proceso de la creación cinematográfica (2015). 